
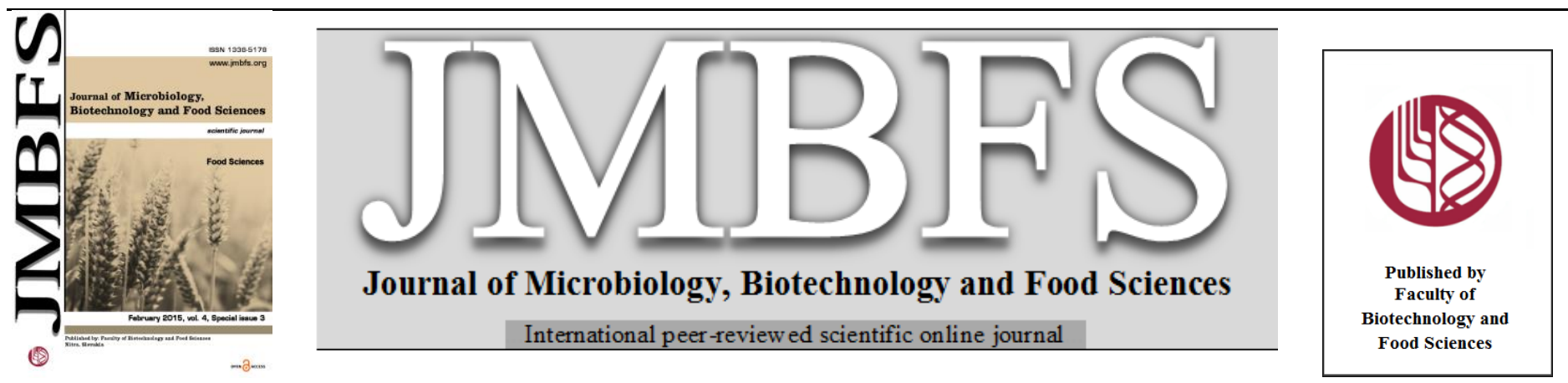

\title{
THE PH VALUE OF BROILER BREAST AND THIGH MUSCLES AFTER ADDITION PROBIOTIC, BEE POLLEN AND PROPOLIS INTO THEIR FEED MIXTURE
}

\author{
Peter Haščík $*^{1}$, Ibrahim Omer Elamin Elimam ${ }^{3}$, Marek Bobko ${ }^{1}$, Miroslava Kačániová ${ }^{2}$, Juraj Čubon̆ ${ }^{1}$, Jana Tkáčovál , Lenka \\ Trembeckál
}

\begin{abstract}
Address(es): doc. Ing. Peter Haščík, PhD.
${ }^{I}$ Slovak University of Agriculture in Nitra, Faculty of Biotechnology and Food Sciences, Department of Animal Products Evaluation and Processing, Tr. A. Hlinku 2, 94976 Nitra, Slovak Republic.

${ }^{2}$ Slovak University of Agriculture in Nitra, Faculty of Biotechnology and Food Sciences, Department of Microbiology, Tr. A. Hlinku 2, 94976 Nitra, Slovak Republic

${ }^{3}$ Dalang University Faculty of Agricultural Sciences, Department of Animal Production, Post.Box 14 dalanj-Sudan.
\end{abstract}

*Corresponding author:peter.hascik@uniag.sk

doi: 10.15414/jmbfs.2015.4.special3.52-54

\begin{abstract}
ARTICLE INFO

ABSTRACT

Received 2. 12. 2014

Revised 10. 12. 2014

Accepted 11. 12. 2014

Published 2. 2. 2015

The present experiment was conducted to evaluate the broiler's Ross 308 breast and thigh muscles pH value after addition probiotic, bee pollen and propolis as supplemental diet. A total of 180 chicks in one day old, which were divided into 6 groups (30): control group T1

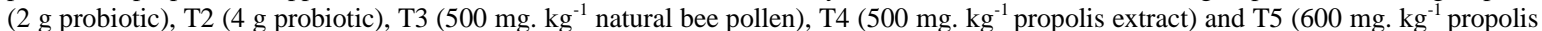
extract). At the end of the experimental period ( 42 days) the broiler has been slaughtered to determinate the $\mathrm{pH}$ value by using $\mathrm{pH}$ meter equipped with an electrode calibrated (Grif 209L apparatus). The results show that the pH value after 45 minutes was lower in the experimental groups compared to control group and there were found significant differences $(\mathrm{P} \leq 0.05)$ between the control group with

Regular article experimental groups, similarly the $\mathrm{pH}$ value after 2 hours in breast muscles was higher in the control group compared to experimental groups, but in the thigh the experimental groups (T1, T2, T3 and T5) were higher than control group except (T4) group. Otherwise, the $\mathrm{pH}$ value after 24 hours was higher in the experimental groups compared to the control except (T4, T5) in the thigh. From the present study, we conclude that the $\mathrm{pH}$ value after 24 hours was higher value in the experimental groups compared to the control group and the bee pollen in the amount $\left(500 \mathrm{mg} \cdot \mathrm{kg}^{-1}\right)$ was given the highest value of $\mathrm{pH}$ value.
\end{abstract}

Keywords: Broiler Ross 308, probiotic, bee pollen, propolis, $\mathrm{pH}$ value

\section{INTRODUCTION}

Worldwide consumption of poultry meat is growing up as in developed well as in developing countries, in 1999 the world production of broiler chickens reached 40 billion and expects continued growth until 2020 (Bilgili, 2002). The rate of $\mathrm{pH}$ decline has been dependent on the activity of glycolytic enzymes just after death; the ultimate $\mathrm{pH}$ is determined by the initial glycogen reserves of the muscle (Janz et al., 2002). A low pH is associated with poor water-holding capacity and poor functionality (Owens et al., 2000; Woelfel et al., 2002) and a high $\mathrm{pH}$ is associated with poor shelf life because it is a more favourable environment for bacteria (Janz et al., 2002). The normal $\mathrm{pH}$ after one hour is about $(6.9-7.1)$ and $\mathrm{pH}$ after 24 hours is about $(5.7-5.9)$ (Ingr, 1996; Čuboň et al., 2005; Haščík et al., 2009).

Bee pollen has been used for many years in both traditional medicine and supplementary nutrition, as well as in alternative diets, mainly due to its nutritional properties and health benefits (Serra et al., 1997; Isla et al., 2001; Almeida-Muradian et al., 2005). As alternative substitutions in nutrition, bee products (pollen, propolis or their extracts) may be employed, because they can have positive influence on health state, economic use of feed and quality of product (Prytzyk et al., 2003; Wang et al., 2004; Haščík et al., 2005a, b, 2007; Angelovičová et al., 2006, 2008; Shalmany and Shivazad, 2006; Seven et al., 2008). Several plant supplements contain substances, which increase the gluttony and digestion (Barreto et al., 2008).

A popular alternative to the use of antibiotics has been the use of probiotics which have been used in poultry for "competitive/exclusion" of bacterial pathogens (Barrow, 1992). The positive effects of probiotics on animals can result either from a direct nutritional effect of the probiotic, or a health effect, with probiotics acting as bioregulators of the intestinal microflora and reinforcing the host's natural altitude defines. There have been numerous studies in humans and animals with the ability of probiotics to change the types and numbers of gut microflora (Endo, 1999; Saulnier, 2007). Gong et al. (2002) define probiotics as health-promoting bacteria inhabiting the gastrointestinal tract of humans and animals.

The present was objected to study the effect addition probiotic, bee pollen and propolis as supplements diet on the broiler breast and thigh muscles $\mathrm{pH}$ value.

\section{MATERIAL AND METHODS}

\section{Animals and diets}

The experiment was implemented at the test poultry station of Slovak University of Agriculture in Nitra. The tested chickens were broiler Ross 308. The experiment content 180 chicks in one day-old, which were divided into 6 groups $(\mathrm{n}=30)$ : control group, T1, T2, T3, T4 and T5 for 42 days. The chickens were bred in cage conditions. Each cage was equipped with feed dispenser and water intake was ensured ad libitum through a self-feed-pump. The temperature was controlled during the fattening period and it was $33^{\circ} \mathrm{C}$ at the first day and every week was reduced about $2{ }^{\circ} \mathrm{C}$ and final temperature was $19{ }^{\circ} \mathrm{C}$. The lighting during the experimental period was continuous. Each group was fed by the same starter complete feed mixture (CFM) HYD-01 (loose structure) from $1^{\text {st }}$ day to $21^{\text {st }}$ days of their age, and from the $22^{\text {nd }}$ to $42^{\text {nd }}$ days of their age, chickens were fed by a complete feed mixture (CFM) HYD-02 (loose structure), in all investigated groups of the experiment. The complete feed mixture HYD-01 and HYD-02 has been produced without antibiotic preparations and coccidiostatics (Table 1). However, they were added to experimental groups such as T1 (2 g probiotic through drinking water), T2 (4 g probiotic through drinking water), to the T3 were added natural bee pollen in the amount (500 mg. $\left.\mathrm{kg}^{-1}\right)$ into feed mixture and to (T4, T5) were added propolis extract in the amount $(500,600$ $\left.\mathrm{mg} \cdot \mathrm{kg}^{-1}\right)$ respectively into feed mixture. 


\section{Sample analysis}

At the end of the fattening period from each experimental group were selected 20 pieces randomly of chickens for slaughter analysis (10 male pieces and 10 female pieces) to determined $\mathrm{pH}$ (45 minutes, 2 and 24 hours after slaughtering) by using a $\mathrm{pH}$ meter equipped with an electrode calibrated (Grif 209L apparatus) at $\mathrm{pH} 4.0$ and 7.0 before measuring. The $\mathrm{pH}$ is easier measured by probe method by inserting a thin electrode directly into the muscle after incision of the muscle. The experimental analysis was evaluated at Department for evaluation and processing of animal products at Faculty of Biotechnology and Food Sciences Slovak University of Agriculture in Nitra.

\section{Statistical analysis}

The results of meat performance (arithmetic mean, standard deviation) were statistically analysed by the statistic program Statgraphics Plus version 5.1 (AV Trading Umex, Dresden, Germany). For the determination of significant differences among the tested groups was used analysis of variance.

Table 1 Composition of the diets

\begin{tabular}{|c|c|c|}
\hline Ingredients [\%] & $\begin{array}{c}\text { Starter } \\
\left(1^{\text {st }} \text { to } 21^{\text {st }} \text { days of age }\right)\end{array}$ & $\begin{array}{c}\text { Grower } \\
\left(22^{\text {nd }} \text { to } 40^{\text {th }} \text { days of age }\right)\end{array}$ \\
\hline Wheat & 35.83 & 31.21 \\
\hline Maize & 35.00 & 40.00 \\
\hline Soybean meal (48 \% N) & 20.00 & 21.00 \\
\hline Fish meal $(71 \% \mathrm{~N})$ & 4.00 & - \\
\hline Dried blood & 1.60 & 2.10 \\
\hline Dried whey & - & 2.20 \\
\hline Ground limestone & 1.00 & 0.80 \\
\hline Monocalcium phosphate & 1.00 & 0.90 \\
\hline Fodder salt & 0.10 & 0.15 \\
\hline Sodium bicarbonate & 0.20 & 0.20 \\
\hline Lysin & 0.10 & 0.06 \\
\hline Methionin & 0.17 & 0.23 \\
\hline Palm kernel oil Bergafat & 0.50 & 0.65 \\
\hline Premix Euromix BR 0,5 \% ${ }^{1}$ & 0.50 & 0.50 \\
\hline
\end{tabular}

\begin{tabular}{lcc}
\hline Nutrient composition [g. $\mathbf{k g}^{-1}$ ] & \\
\hline Crude protein & 210.39 & 191.47 \\
Fibre & 29.78 & 29.89 \\
Ash & 24.56 & 17.77 \\
$\mathrm{Ca}$ & 8.24 & 7.13 \\
$\mathrm{P}$ & 6.76 & 6.11 \\
$\mathrm{Mg}$ & 1.39 & 1.37 \\
Linoleic acid & 12.77 & 13.41 \\
$\mathrm{ME}_{\mathrm{N}}\left(\mathrm{MJ} . \mathrm{kg}^{-1}\right)$ & 12.00 & 12.08 \\
\hline
\end{tabular}

Legend: ${ }^{1}$ active substances per kilogram of premix: vitamin A $2500000 \mathrm{IU}$; vitamin E 20000 mg; vitamin D3 800000 IU; niacin 12000 mg; d-pantothenic acid $3000 \mathrm{mg}$; riboflavin $1800 \mathrm{mg}$; pyridoxine $1200 \mathrm{mg}$; thiamine $600 \mathrm{mg}$; menadione $800 \mathrm{mg}$; ascorbic acid $20000 \mathrm{mg}$; folic acid $400 \mathrm{mg}$; biotin $40 \mathrm{mg}$; kobalamin 8.0 mg; choline 100000 mg; betaine 50000 mg; Mn 20000 mg; Zn 16000 mg; Fe 14000 mg; Cu 2400 mg; Co 80 mg; I 200 mg; Se 50 mg

Table $2 \mathrm{pH}$ of the thigh muscles after addition probiotic through drinking water $(\mathrm{g})$, natural bee pollen $\left(\mathrm{mg}^{\mathrm{k}} \mathrm{kg}^{-1}\right)$ and propolis extract $\left(\mathrm{mg} . \mathrm{kg}^{-1}\right)$

\begin{tabular}{ccccccc}
\hline Indicators & $\mathbf{C}$ & T1 (2 g probiotic) & T2 (4 g probiotic) & T3 (500 g bee pollen) & T4 (500 g propolis) & T5 (600 g propolis) \\
\hline $\mathbf{n}$ & 30 & 30 & 30 & 30 & 30 & 30 \\
$\mathbf{4 5}$ minutes & $6.24 \pm 0.13^{\mathrm{a}}$ & $6.07 \pm 0.16^{\mathrm{b}}$ & $6.08 \pm 0.11^{\mathrm{b}}$ & $6.17 \pm 0.19^{\mathrm{a}}$ & $6.08 \pm 0.16^{\mathrm{b}}$ & $6.08 \pm 0.14^{\mathrm{b}}$ \\
$\mathbf{2}$ hours & $5.94 \pm 0.14$ & $5.86 \pm 0.10$ & $5.83 \pm 0.11$ & $5.89 \pm 0.14$ & $5.89 \pm 0.16$ \\
$\mathbf{2 4}$ hours & $5.84 \pm 0.12^{\mathrm{a}}$ & $5.85 \pm 0.07^{\mathrm{a}}$ & $5.86 \pm 0.06^{\mathrm{a}}$ & $5.96 \pm 0.12^{\mathrm{b}}$ & $5.86 \pm 0.10^{\mathrm{ab}}$ & $5.99 \pm 0.12 \pm 0.04^{\mathrm{ab}}$ \\
\hline *C: control group, ${ }^{*} \mathrm{~T} 1, \mathrm{~T} 2, \mathrm{~T} 3, \mathrm{~T} 4, \mathrm{~T} 5$ experimental groups; ${ }^{\mathrm{a}, \mathrm{b}, \mathrm{c}}$ : values are expressed as means \pm standard deviation $(\mathrm{n}=30)(\mathrm{P} \leq 0.05)$
\end{tabular}

Table $3 \mathrm{pH}$ of the thigh muscles after addition probiotic through drinking water $(\mathrm{g})$, natural bee pollen $\left(\mathrm{mg}^{\mathrm{k}} \mathrm{kg}^{-1}\right)$ and propolis extract (mg.kg $\left.\mathrm{g}^{-1}\right)$

\begin{tabular}{ccccccc}
\hline Indicators & $\mathbf{C}$ & T1 (2 g probiotic) & T2 $(\mathbf{4}$ g probiotic) & T3 (500 g bee pollen) & T4 (500 g propolis) & T5 (600 g propolis) \\
\hline $\mathbf{n}$ & 30 & 30 & 30 & 30 & 30 & 30 \\
$\mathbf{4 5}$ minutes & $6.59 \pm 0.17^{\mathrm{ab}}$ & $6.48 \pm 0.14^{\mathrm{a}}$ & $6.50 \pm 0.13^{\mathrm{a}}$ & $6.65 \pm 0.13^{\mathrm{b}}$ & $6.53 \pm 0.15^{\mathrm{ab}}$ & $6.56 \pm 0.12^{\mathrm{ab}}$ \\
$\mathbf{2}$ hours & $6.45 \pm 0.16^{\mathrm{ab}}$ & $6.54 \pm 0.18^{\mathrm{ab}}$ & $6.52 \pm 0.12^{\mathrm{ab}}$ & $6.63 \pm 0.14^{\mathrm{a}}$ & $6.42 \pm 0.16^{\mathrm{b}}$ & $6.47 \pm 0.15^{\mathrm{b}}$ \\
$\mathbf{2 4}$ hours & $6.29 \pm 0.17^{\mathrm{ab}}$ & $6.36 \pm 0.19^{\text {ab }}$ & $6.34 \pm 0.17^{\mathrm{ab}}$ & $6.37 \pm 0.12^{\mathrm{a}}$ & $6.28 \pm 0.14^{\mathrm{ab}}$ \\
\hline *C: control group, ${ }^{*} \mathrm{~T} 1, \mathrm{~T} 2, \mathrm{~T} 3, \mathrm{~T} 4, \mathrm{~T} 5$ experimental groups; ${ }^{\mathrm{a}, \mathrm{b}, \mathrm{c}}$ : values are expressed as means \pm standard deviation $(\mathrm{n}=30)(\mathrm{P} \leq 0.05)$
\end{tabular}

\section{RESULTS AND DISCUSSION}

The $\mathrm{pH}$ value of the broiler Ross 308 chickens breast and thigh muscles were shown in tables $(1,2)$ where they shows that the $\mathrm{pH}$ value after 45 minutes of the broiler breast and thigh muscles in control group $(6.24 \pm 0.13,6.59 \pm 0.17)$ was higher than experimental groups T1 $(6.07 \pm 0.16,6.48 \pm 0.14)$, T2 $(6.08 \pm 0.11$, $6.50 \pm 0.13), \quad \mathrm{T} 3 \quad(6.17 \pm 0.19, \quad 6.65 \pm 0.13), \quad \mathrm{T} 4 \quad(6.08 \pm 0.16,6.53 \pm 0.15), \quad$ T5 $(6.08 \pm 0.14,6.56 \pm 0.12)$ and there were found significant differences $(\mathrm{P} \leq 0.05)$ in breast muscles between control group and experimental groups (T1, T2, T3, T4 and T5). Otherwise, the $\mathrm{pH}$ value after 2 hours of the breast in the control group $(5.94 \pm 0.14)$ was higher than T1 $(5.86 \pm 0.10)$, T2 $(5.83 \pm 0.11), \mathrm{T} 3(5.89 \pm 0.14), \mathrm{T} 4$ $(5.89 \pm 0.16)$ and $\mathrm{T} 5(5.89 \pm 0.12)$ and they're not significant differences $(\mathrm{P} \geq 0.05)$ between the groups. On the other hand the $\mathrm{pH}$ value after 2 hours in the thigh was lower in the control group $(6.45 \pm 0.16)$ compared to experimental groups T1 $(6.54 \pm 0.18), \quad \mathrm{T} 2 \quad(6.52 \pm 0.12), \quad \mathrm{T} 3 \quad(6.63 \pm 0.14), \quad \mathrm{T} 5 \quad(6.47 \pm 0.15)$ except $\mathrm{T} 4$ $(6.42 \pm 0.16)$ it was lower than the control group.

Moreover, the $\mathrm{pH}$ value after 24 hours in breast and thigh was lower in control group $(5.84 \pm 0.12,6.29 \pm 0.17)$ compared to experimental groups $\mathrm{T} 1$ $(5.85 \pm 0.07,6.36 \pm 0.19)$, T2 $(5.86 \pm 0.06,6.34 \pm 0.17)$, T3 $(5.96 \pm 0.12,6.37 \pm 0.12)$
T4 $(5.86 \pm 0.10,6.28 \pm 0.14)$ and T5 $(5.91 \pm 0.04,6.24 \pm 0.12)$ except in thigh there were found that the (T4, T5) groups was lower the control group, however they were found significant differences $(\mathrm{P} \leq 0.05)$ in breast between the control groups and $\mathrm{T} 3$.

The $\mathrm{pH}$ value results of the broiler breast and thigh are confirm Hašćík et al. (2013) who was studied the effect of the bee pollen on broiler Ross (308) $\mathrm{pH}$ value. Similarly the present study is support Sulcerova et al. (2011) who added bee and propolis into broiler (Ross 308) feed mixture. Also, our results are in agreement with Elimam et al. (2012) who studied the impact of the bee pollen on broiler breast and the thigh muscles. Moreover, our findings confirm the study of (Hašč́k et al., 2010) who studies the effect of the probiotic on the broiler $\mathrm{pH}$ value. The reason why the bee pollen and propolis improves the meat $\mathrm{pH}$ value because bee pollen and propolis decreases the meat oxidative stability, we knew that when meat oxidation is an autocatalytic process occurring in food and biological membranes, which leads to significant damage of the food quality they can be used as substrates for initiation of oxidative processes (Haščík et al. 2011; Elimam, 2014). Also the main catalysts of oxidation are highly reactive free radicals as superoxide anion $(\mathrm{O}-2)$, hydroxyl radical $\left(\mathrm{OH}^{\circ}\right)$, proxyl radicals $\left(\mathrm{ROO}^{\circ}\right)$, which contain one or more free electrons all this processing may 
decrease the meat $\mathrm{pH}$ value, so when the bee pollen inhibit meat oxidation that the reason explains why bee pollen improves the meat $\mathrm{pH}$ value (Marcinčák et al., 2005).

Moreover, bee pollen is antibacterial pathogens (Basim et al., 2006; Kňazovická et al., 2009) also bee pollen and propolis effect on the meat $\mathrm{pH}$ because the bee pollen gathered is considered as a valuable functional food with varied enhancing effects in health (Bogdanov, 2004). According to this reason we conclude the bee pollen and propolis improve meat $\mathrm{pH}$ value.

\section{CONCLUSION}

The recent study has concluded the that the $\mathrm{pH}$ value after 24 hours was higher in the experimental groups compared to the control group and bee pollen in amount $\left(500 \mathrm{mg} \cdot \mathrm{kg}^{-1}\right)$ has been given the highest value of the $\mathrm{pH}$ compared to the probiotic and propolis, however, the propolis was given the lowest $\mathrm{pH}$ value.

Acknowledgments: The work was financially supported by project VEGA1/0129/13.

\section{REFERENCES}

ALMEIDA-MURADIAN, L. B., PAMPLONA, L. C., COIMBRA, S., BARTH, O. M. 2005 Chemical composition and botanical evaluation of dried bee pollen pellets. Journal of Food Composition and Analysis, Rome, 18 (1), 105-111. http://dx.doi.org/10.1016/j.jfca.2003.10.008

ANGELOVIČOVÁ, M., LADYKOVÁ, M., LIPTAIOVÁ, D., MOČÁR, K., ŠTOFAN, D. 2008. Riešenie náhrady kŕmnych antibiotic rastlinnými silicami pri výrobe kuracieho mäsa. IX. Potravinárska konferencia: Otvorené fórum o stave bezpečnosti, kvality a kontroly potravín, Bratislava, 41-45.

ANGELOVIČOVÁ, M., MELLEN, M., ANGELOVIČ, M. 2006. Uplatnenie biotechnologického postupu náhrady kŕmneho antibiotika premixom škoricovej silice vo výžive výkrmových kurčiat. Biotechnológie, JU: České Budějovice, 134-136, ISBN 8085- 645-53-X

BARRETO, M. S. R., MENTEN, J. F. M., RACANICCI, A. M. C., PEREIRA, P. W. Z., RIZZO, P. V. 2008. Plant extracts used as growth promoters in broilers. Brazilian Journal of Poultry Science, 10, (2), 109-115 http://dx.doi.org/10.1590/s1516-635x2008000200006

BARROW, P. A. 1992. Probiotics for chickens. Fuller R. (Ed), Probiotics. The Scientific Basis. Chapman and Hall, London, 225-257. http://dx.doi.org/10.1007/978-94-011-2364-8_10

BASIM, E., BASIM H., OZCAN. M. 2006. Antibacterial activities of turkish pollen and propolis extracts against plant bacterial pathogens. Journal of Food Engineering, 77, 992-996. http://dx.doi.org/10.1016/j.jfoodeng.2005.08.027

BILGILI, S. F. 2002. Poultry meat processing and marketing - what does the future hold? Poultry International, 12-22.

BOGDANOV, S. 2004. Quality and standards of pollen and beeswax. Apiacta, 38, 334-341.

ČUBOŇ, J., HAŠČÍK, P., MOJTO, J., KAČÁNIOVÁ, M. 2005. Vplyv aplikácie mliečnanu sodného na kvalitu mladého hovädzieho mäsa. Pol'nohospodárstvo, 51, 580-584.

ELIMAM, I. O. E. 2014. Meat performance and meat quality of broiler chickens after application of bee pollen in their feed mixture. PhD dissertation, FBP17323-49794

ELIMAM, I. O. E., HAŠČÍK, P., GARLÍK. P. 2012. The effect of addition bee pollen to feed mixtures of broiler Ross 308 on $\mathrm{pH}$ value of the breast and thighs muscles. VI. Vedecká konferencia doktorandov s medzinárodnou účast'ou, Nitra, 25. 4. 2012, 158-161.

ENDO, T., NAKANO, M., SHIMIZU, S., FUKUSHIMA, M., MIYOSHI, S. 1999. Effect of a probiotic on the lipid metabolism of cocks fed on cholesterolenriched diet. Bioscience Biotec. Biochem., 63, 1569-1575 http://dx.doi.org/10.1271/bbb.63.1569

GONG, J., FORSTER, R. J., YU, H., CHAMBERS, J. R., WHEAT CRAFT, R., SABOUR, P. M., SHU, C. 2002. Molecular analysis of bacterial populations in the ileum of broiler chickens and comparision with bacteria in the cecum. FEMS Microbiol. Ecolology, 41, 171-179. http://dx.doi.org/10.1016/s0168 6496(02)00291-X

HAŠČÍK, P., ČUBOŇ, J., HORNIAKOVÁ, E., KRIVÁNEK, L., KULÍŠEK, V. 2005a.Vzt'ah medzi aplikáciou probiotického preparátu a množstvom abdominálneho tuku u výkrmových kurčiat. Pol'nohospodárstvo, 51, 574-579. HAŠČÍK, P., WEIS, J., ČUBOŇ, J., KULÍŠEK, V., MAKOVICKÝ, P., KAČÁNIOVÁ, M. 2005b.Vplyv probiotického preparátu v KKZ brojlerových kurčiat ROSS 308 na chemické zloženie mäsa. Acta fytotechnica et zootechnica, 8, 20-24.

HAŠČÍK, P., BOBKO, M., KAČÁNIOVÁ, M., ČUBOŇ, J., KULÍŠEK, V., PAVLIČOVÁ, S. 2007. Vplyv probiotického preparátu na tvorbu tuku v tele kurčiat. VII. Celoslovenský seminár z fyziológie živočíchov, Nitra : SPU, s. 85 91, ISBN 978-80-8069-886-7-0.

HAŠČÍK, P., BOBKO, M., ČUBOŇ, J., WEIS, J. 2009. Spracovanie hydiny a minoritných živočíšnych produktov.SPU Nitra, 138 s., ISBN 978-80-552-0176-4.
HAŠČÍK, P., MIHOK, M., KAČÁNIOVÁ, M., ČUBOŇ, J., BOBKO, M., PRÍVARA, Š., VAVRIŠINOVÁ, K., ARPÁŠOVÁ, H., KUNOVÁ, S 2010.Effect of multistrain probiotic application on changes in breast and thigh muscle of Hybro broiler chickens post mortem. Potravinárstvo, special issue, 143-151.

HAŠČÍK, P., ELIMAM, I., BOBKO, M., KAČÁNIOVÁ, M., POCHOP, J., GARLÍK, J., KROČKO, M., ČUBOŇ, J., VAVRIŠINOVÁ, K., ARPÁŠOVÁ, H., CAPCAROVÁ, M., BENCZOVÁ, E. 2011. Oxidative stability of chicken meat after pollen extract Application in their diet. Journal of Microbiology, Biotechnology and Food Sciences, 1, 70-82.

HAŠČÍK, P., ELIMAM, I., GARLÍK, J., BOBKO, M., ČUBOŇ, J. 2013. The effect of bee pollen as supplement dietary for meat $\mathrm{pH}$, cooling and freezing loses on broiler chickens meat. Animal welfare, ethology and housing systems journal, 9 (3), Különszám/Special Issue Gödöllö, 477-482.

INGR, I. 1996. Technologické vlastnosti masa a jejich postmortální vývoj. Maso, 7, 6-10.

ISLA, M. I., MORENO, M. I. N., SAMPIETRO, A. R., VATTUONE, M. A 2001 Antioxidant activity of Argentine propolis extracts. Journal of Ethnopharmacology, Leiden, 76, 165-170. http://dx.doi.org/10.1016/s0378 8741(01)00231-8

JANZ, J. A. M., AALHUS, J. L., PRICE, M. A. 2002. Fibre type characteristics and post mortem glycolysis of bison (Bison bison bison) longissimus lumborum. Journal of Animal Science, 82, 259-262. http://dx.doi.org/10.4141/a00-114 KŇAZOVICKÁ, V., MELICH, M., KAČÁNIOVÁ, M., FIKSELOVÁ, M. HAŠČIK, P., CHLEBO, R. 2009.Antimicrobial activity of selected bee products. Acta fytotechnica et zootechnica - mimoriadne číslo, 280-285.

MARCINĆÁK, S., POPELKA, O., BYSTRICKÝ, O., HUSSEIN, O. HUDECOVÁ, O. 2005. Oxidative stability of meat and meat products after feeding of broiler chickens with additional amounts of vitamin $\mathrm{E}$ and rosemary. Prethodnopriopćenje, VII, 34-39.

OWENS, C. M., SAMS, A. R. 2000. The influence of transportation on turkey $\begin{array}{llll}\text { meat } \quad \text { quality. } & \text { Poultry } & \text { Science, } & \text { 1204-1207. }\end{array}$ http://dx.doi.org/10.1093/ps/79.8.1204

PRYTZYK, E., DANTAS, A. P., SALOMÃO, K., PEREIRA, A. S. BANKOVA, V. S., DE CASTRO, S. L., AQUINO NETO, F. R. 2003. Flavonoids and trypanocidal activity of Bulgarian propolis. Journal of Ethnopharmacology, 88, 189-193. http://dx.doi.org/10.1016/s0378 8741(03)00210-1

SAULNIER, D. M. 2007. Identification of prebiotic fructooligosaccharide metabolism in Lactobacillus plantarum WCFS1 through microarrays. Apply Environ. Microbiol., 73, 1753-1765. http://dx.doi.org/10.1128/aem.01151-06 SERRA BONVEHI, J., ESCOLA, JORDA, R. 1997. Nutrient composition and microbiological quality of honey bee collected pollen in Spain.Journal of $\begin{array}{llll}\text { Agriculture } \text { and } & \text { 725-732, }\end{array}$ http://dx.doi.org/10.1021/jf960265q

SEVEN, T. P., SEVEN, I., YILMAZ, M., SIMSEK, G. Ü. 2008. The effects of Turkish propolis on growth and carcass characteristics in broilers under heat stress. Animal Feed Science and Technology, 146, 137-148. http://dx.doi.org/10.1016/j.anifeedsci.2007.11.003

SHALMANY, K. S., SHIVAZAD, M. 2006. The effect of diet Propolis supplementation on Ross broiler chicks performance. International Journal of Poultry Science, 5, 84-88. http://dx.doi.org/10.3923/ijps.2006.84.88

ŠULCEROVÁ, H., MIHOK, M., JŮZL, M., HAŠČÍK, P. 2011. Effect of addition of pollen and propolis to feeding mixture during the production of broiler chickens Ross 308 to the colour for thigh and breast muscles and $\mathrm{pH}$ determination. Acta Universitatis Agriculturae et Silviculturae Mendelianae Brunensis, 44, 359-366. http://dx.doi.org/10.11118/actaun201159060359

WANG, B. J., LIEN, Y. H., YU, Z. R. 2004. Supercritical fluid extractive fractionation - study of the antioxidant activities of propolis. Food Chemistry, 86 237-243. http://dx.doi.org/10.1016/j.foodchem.2003.09.031

WOELFEL, R. L., OWENS, C. M., HIRSCHLER, E. M., MARTINEZ DAWSON, R., SAMS, A. R. 2002. The characterization and incidence of pale, soft, and exudative broiler meat in a commercial processing plant. Poultry Science, 81 , 579-584. http://dx.doi.org/10.1093/ps/81.4.579 